特 集：速報, 動物園および野生動物の感染症 2002

第 8 回日本野生動物医学会大会 自由集会 2002 年 9 月7日 フォレストパーつあだたら

\title{
動物園動物および野生動物の感染症
}

柳井徳磨1), 杉山 誠 ${ }^{2}$, 平田暁大 ${ }^{12}$, 酒井洋樹 ${ }^{1}$, 椓木利昭 ${ }^{1)}$, 吉川泰弘 ${ }^{3)}$

1) 岐皁大学農学部家畜病理学講座 干 501-1193 岐阜県岐阜市柳戸 1-1

2) 岐阜大学農学部獣医公衆衛生学講座 T 501-1193 岐阜県岐阜市柳戸 1-1

3) 東京大学大学院農学生命科学研究科実験動物学教室 $\overline{\mathbf{T}}$ 113-8657 東京都文京区弥生 1-1

\section{Infectious Diseases in Zoo and Wildlife}

Tokuma YANAI ${ }^{11}$, Makoto SUGIYAMA ${ }^{2)}$, Akihiko HIRATA ${ }^{1)}$

Hiroki SAKAI ${ }^{1}$, Toshiaki MASEGI ${ }^{1}$, Yasuhiro YOSHIKAWA ${ }^{3)}$

1) Department of Veterinary Pathology, Faculty of Agriculture, Gifu University,

1-1 Yanagido, Gifu 501-1193, Japan

2) Department of Veterinary Public Health Pathology, Faculty of Agriculture, Gifu University,

1-1 Yanagido, Gifu 501-1193, Japan

3) Department of Biomedical Science, Faculty of Agriculture, The University of Tokyo,

Yayoi 1-1, Bunkyo-ku 113-8657, Japan

\begin{abstract}
It is very important to monitor infectious diseases of zoo animals and wildlife to prevent additional losses of animals, which contribute a lot to wildlife management and conservation, domestic animal hygiene and prevention of zoonosis. Thus, we would like to have a workshop " Infectious diseases 2002 in zoo animals and wildlife" to share up-to-date information for disease control. As infections to be in an emergency or warned, the following infections were focused; chlamydiosis in zoo birds and moos, yersiniosis in nonhuman primates, cryptosporidiosis in reptiles and spongiform encephalopathy in zoo animals and wildlife. Besides, several possible infections to invade into Japan or of great concern to breakout are discussed. It would be desirable to settle a network for infectious diseases of zoo animals and wildlife to prevent animal loss and zoonosis.
\end{abstract}

Key Words: infectious diseases, zoo animals, wildlife

\section{はじめに}

最近，動物園を中心に人獣共通感染症や野生動物の保護 管理などの観点から見過ごせない二, 三の感染症が発生し ている。これまで，動物園動物抢よび野生動物の感染症に 関しては，情報交換の場が少ないため必要な情報の入手が 困難であり，また，正確な情報も伝わりにくかった。その ため, 筆者らは第 8 回野生動物医学会 (福島)において, 浇 口俊夫大会長の理解を得て「速報, 動物園および野生動物
感染症 2002」と題するワークショップ(自由集会)を開催 し, 緊急度の高い野生動物の感染症に関する情報交換を 行った。ここでは, ワークショップ「速報, 野生動物感染 症 2002」の概要, 野生動物医学における感染症モニタリン グの意義, 今後発生が予想される感染症(特に西ナイルウイ ルス), 野生動物感染症ネットワークの必要性について述べ る。 


\section{なぜワークショプ「速報, 動物園および野生 動物感染症 2002」なのか}

感染症には未知の部分が多く含まれるため，人久に恐怖 を与え，誤った情報が風聞として広まり，その結果社会に パニックを引き起こすことが，牛海綿状脳症 (BSE)の事例 からも明らかである $[1]$ 。パニックを防ぐためには，当事 者が豊富な情報と経験を有する専門家と直接接触し, 情報 交換して疑問を晴らすことが必要である。また，同時に感 染症の発生を前提とした危機管理プログラムの整備も必要 である。そのため，本ワークショップでは，緊急性の高い 野生動物の感染症に着目し，それぞれの專門家に病原体の 特徵, 事例を中心とした発生状況, 対策について示しても らい，少なくとも「不明な点は誰にコンサルタントを求め れば良いか」を明らかにした。以下に，ワークショップ演 者と演題の概要について示す。

1. 動物園におけるクラミジア症(鳥類抢よびへラジカ)

福士秀人 (岐阜大学農学部)

鳥類館抽よび動物園におけるクラミジア症の発生をオウ ムとへラジカの例をもとに概説し, 同感染症の公衆衛生上 の重要性に触れ，危機管理についても提言した。

2. サル類におけるエルシニア症

a 。リスザルのエルシニア症

宇根有美 (麻布大学・病理)

b . チンパンジーのエルシニア症

鵜殿俊治 (三和化学研究所)

サル類におけるエルシニア症に関して，新世界ザルのリ スザルと類人猿であるチンパンジーでの発生例について, 発生状況や病理学的特徴を分かりやすく解説した。

3. 爬虫類のクリプトスポリジウム感染

黒木俊郎 (神奈川県衛生研究所)

我が国に扔ける飼育下抢よび野生の爬虫類におけるクリ プトスポリジウム症の淫浸状況を解説し，日本産希少爬虫 類に同感染症が与える影響を警告の意味を含めて紹介し た。

4. 野生動物に抢ける海綿状脳症

杉山 誠(岐阜大学農学部)

海外の野生動物に抢ける海綿状脳症の発生について紹介 した。ヨーロッパの動物園における野生ネコ科動物におけ る BSEの発生状況, さらに今後問題になる北米の野生シ
力類における海綿状脳症の発生についてレビューした [2]。

今後とも, 筆者らは「野生動物感染症ワークショップ」を 継続して開催し, 本ワークショップを通じて, 感染症情報 の適宜な交換に努めたい。

\section{野生動物における感染症のモニタリングの必要性}

野生動物に発生した感染症は, その動物群の個体減少を 引き起こすだけでなく, 周囲の地域における, 畜産業や社 会に少なからず影響を及ぼす場合もある。野生動物の感染 症をモニタリングする意義としては，大きく分けて次の 3 つが考えられる。

\section{野生動物個体数への影響（保護管理）}

野生動物における感染症は, その個体数の減少の極めて 大きな要因となる。感染症が発生した動物種が希少種ある いは絶滅危惧種であれば, 感染が種の絶滅㳊繫がる負の要 因となり，あたかも崖っぷちに立った動物を，一押しで断 崖に落とすに等しい。絶滅種のトキの飼育では, アジや八 夕ハ夕を給慨すると, それらに寄生する線虫による内臓障 害と, 引き続く腹腔出血により, 少なからず貴重な個体が 失われたが，人工餌に切り替えることで防止することがで きた [3]。また, 希少種であるツシマヤマネコの著しい個 体数減少に関しては, 交通事故などの直接的な要因以外に, FIV などの家猫に由来する感染症の影響も少なくないと 考えられている。保護鳥のライ鳥に関して, 最近, 家禽の 感染症であるロイコチトゾーンの感染が確認されている。 また，タンチョウなどツル類では，しばしばへパトゾーン あるいはコクシジウム様の原虫の濃厚感染が整死の原因と なるが，原虫の種については同定に至っていない［4]。

近年, 比較的個体数が多い野生動物についても, 家畜や ペットの感染症が，接触あるいは排泄物を介して野生動物 に伝播流行し, 保護管理の点からも問題視されている。各 地の都市近郊に棲息する夕ヌキには，犬由来と考えられる ヒゼンダニの濃厚感染による重度の疥癖症がしばしば認め られる。重度感染例では, 皮虐に無数のトンネルを形成す るため, 皮虐は著しく肥厚し二次感染を起こし次第に衰弱 する [5]（図 1)。また，ハクビシン，タヌキでは，極めて 劇症のイヌジステンパーウイルス感染症が, 周期的に流行 している。肺, 腎孟移行上皮, 膀胱に大型かつ多数の封入 体を形成するのが特徴で, イヌに比べ高い感受性と致死率 を示す $[6,7]$ 。ジステンパーウイルスは, イヌ科動物以外 


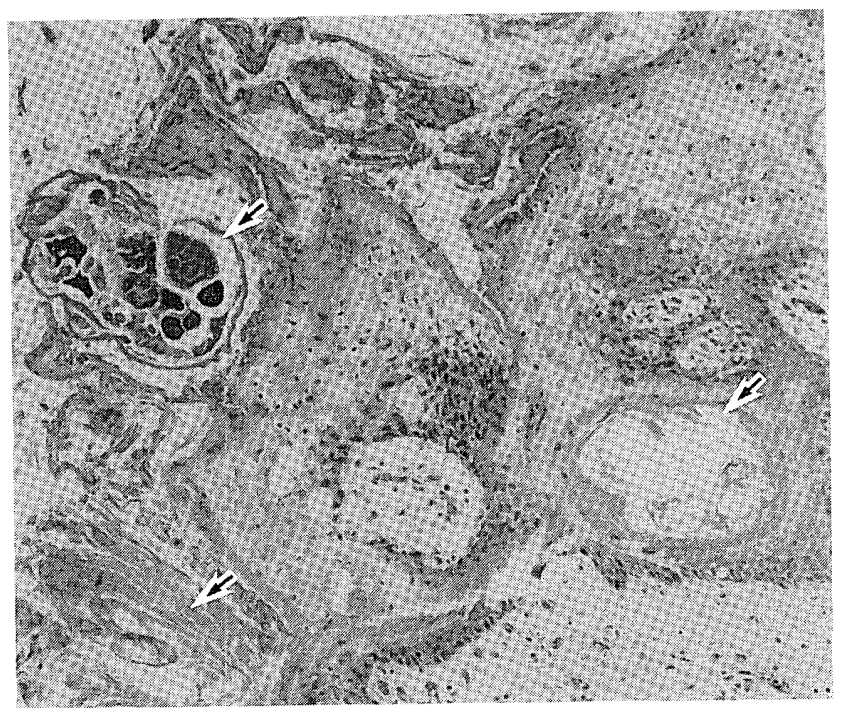

図 1 タヌキの皮瘁疥癬症

皮膚にトンネルを形成(矢印)。HE 染色。

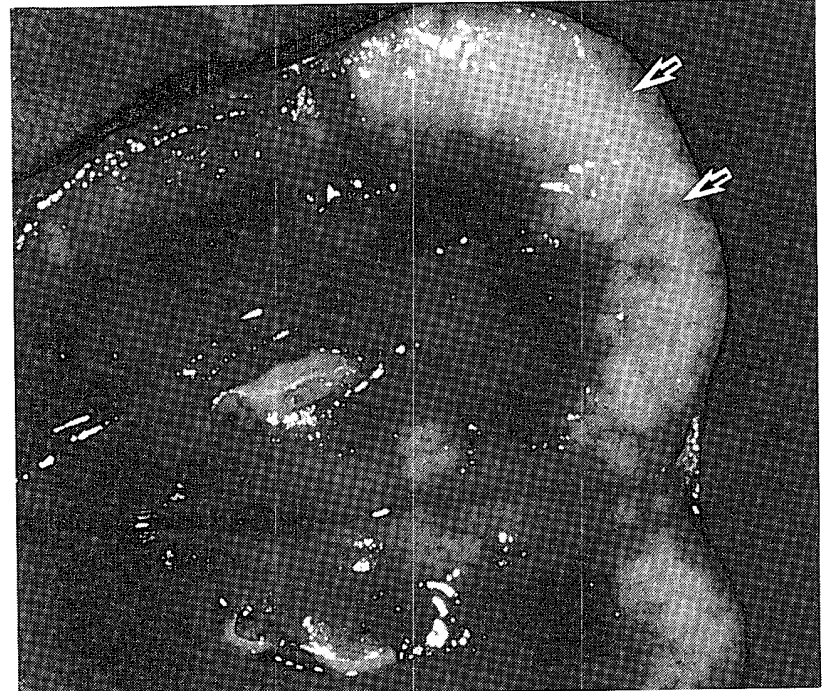

図 2 マヌルネコの FIP 病変

腎臓に打ける化膿性肉芽腫形成(矢印)。

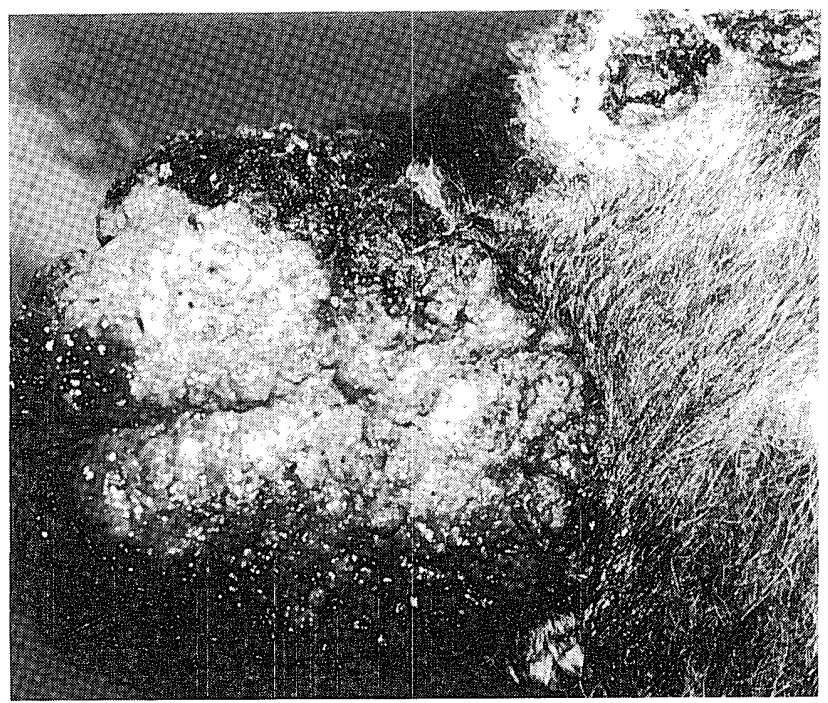

図 3 ニホンカモシカのパラポックス症 口唇部の高度な肥厚

産野生イノシシでは, 不顕性感染を示し, reservoir となり うるので，検疫上注意が必要である $[13]$ 。一方，我が国で は中部および近畿地方の山岳地带に棲息するニホンカモシ カに，口唇や陰部の著明な丘疹(図 3) を形成するパラポッ クスウイルス感染が周期的にみられ，個体数減少をもたら している。流行地内にある山間の羊牧場では，ニホンカモ シカから伝播したと考えられるパラポックス症の発生が羊 群に認められ，力モシ力の感染材料から実験的に幼若羊に 
柳井徳磨ら

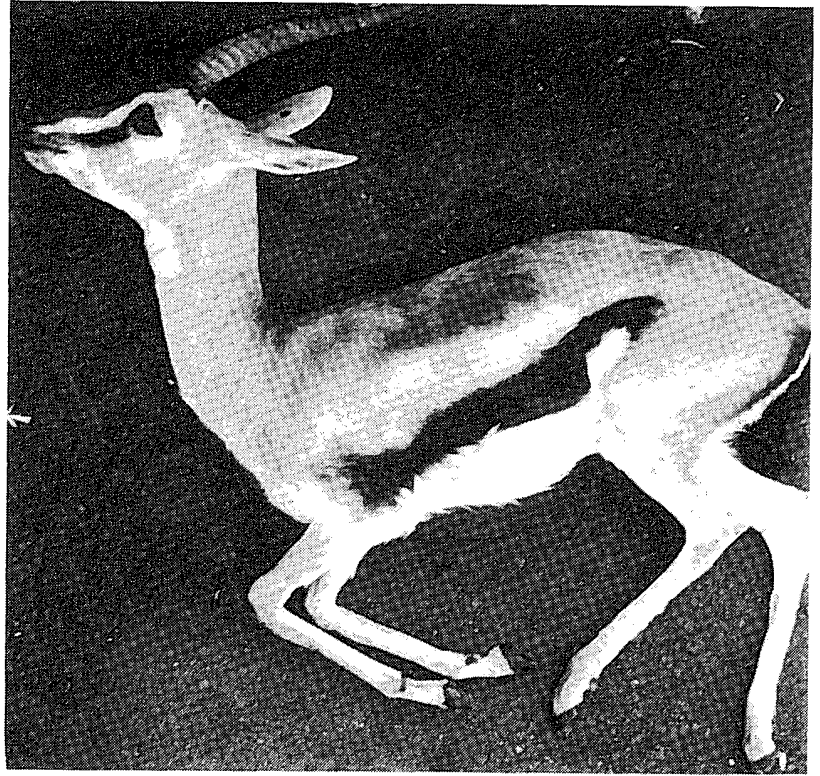

図 4 EHV-9による脳炎で整死したトムソンガゼル

同様な病変を引き起こすことが証明された $[14]$ 。

ところで, 野生動物は依然として，未知の新興感染症の reservoir である可能性を常に考慮すべきである。特にアフ リカや東南アジアなど熱帯雨林から搬入した動物の検疫に は注意が必要である。筆者らは, 動物園でトムソンガゼル の集団脳炎例を検索する機会を得た [15]（図 4)。䌘死した ガゼルの脳から新種のウマヘルペスウイルスである $\mathrm{EHV}$ -9を分離した。EHV-9 は経鼻接種によりマウス,ラット, 八ムスターなどげっ歯類, 反然類では山羊, 食肉類では犬 および猫(図 5)に劇症のウイルス脳炎を引き起こしたこと から, 広い宿主域を有する新興感染症となりうることを明 らかにした [16-19]。馬では, EHV-9を接種しても中等度 の脳炎しか示さず致死的ではないことから，シマウマなど ウマ科の動物が本来の宿主と考えられた $[21]$ 。ウイルス感 染の場合, 異宿主では本来の宿主におけるよりも強い病原 性を発揮する傾向がある。

\section{野生動物から人へ(人獣共通感染症)}

野生動物や動物園動物から人へ伝達される人獣共通感染 症の伝播を防止するために, 動物側の感染症の定期的モ二 タリングを実施する必要がある。野生動物の感染症が人に 伝播される場合，幾つかのパターンがある。

現在，エキゾチックペットブームにより年間 380 万頭と 推定される種々の爬虫類, 小動物, 愛玩鳥類が輸入されて いる。また，動物園でも展示用として様々な種類の動物を

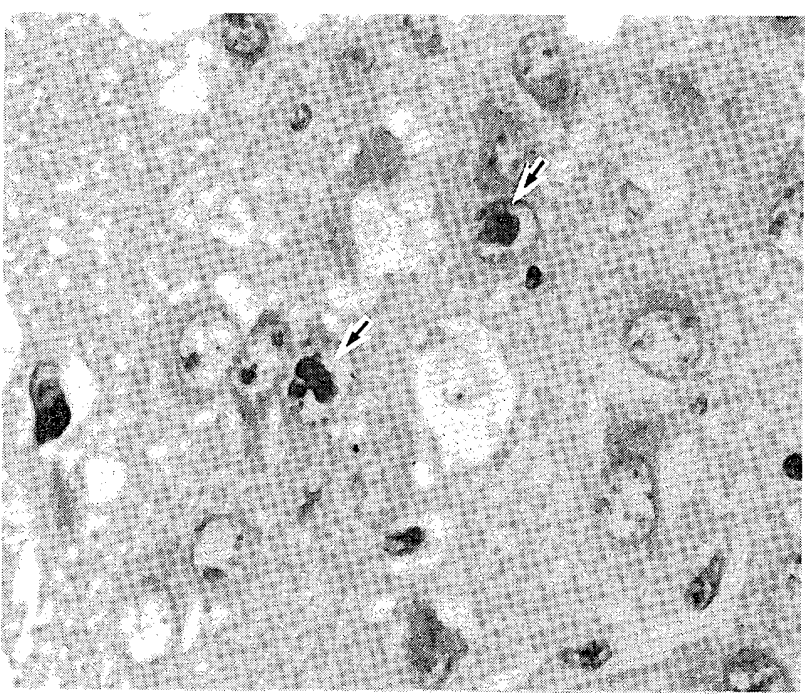

図 $5 \quad \mathrm{EHV}-9$ 接種ビーグル犬に抢けるウイルス性脳炎 核内封入体 (矢印)。

多数輸入している。これらの動物での感染が危惧されてい るのは, 飼い主と動物の接触が濃密なため, あるいは展示 により感染の機会が多く, 感染力の弱い病原体でも感染す ること。また，野生動物が病原体の reservoir となり，その 際外見上健康な場合が多いこと。さらに, EHV-9で述べた 通り, ウイルスは異宿主(人)でより強い病原性を示すこと

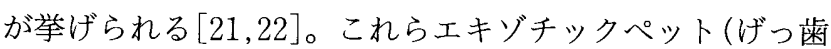
類, 鳥類, 爬虫類)が, 原因と考えられる感染症としては, オウム病, サルモネラ症, カンピロバクター症, 仮性結核 症，トキソプラズマ症，レプトスピラ症などがあげられる [21]。

また，農業開発やアウトドアブームで，今まで人が入ら なかった熱帯雨林や森林，草原地帯に人が踏み込むことに よって，未知あるいは既知の病原体に接触し感染すること がある。1998 年マレーシアで突然ニパウイルス感染症によ る集団脳炎が発生し，患者 26 名が同年死亡した [23］。翌 年はさらに多数の患者が死亡し，ヘンドラウイルス類似の ニパウイルスが分離された。人は豚を通じて感染したが, 自 然宿主はオオコオモリの幾つかの種であると推定された。 オオコウモリは，ニパウイルスだけでなく，新しいLyssa ウイルスや末知のウイルスの自然宿主となっている可能性 が高く，何でもありの，一種パンドラの箱であると認識す べきである [23]。一方, 北米(図 6), 北欧, 北海道の森林 地帯では，ボレリア感染により引き起こされるライム病の 


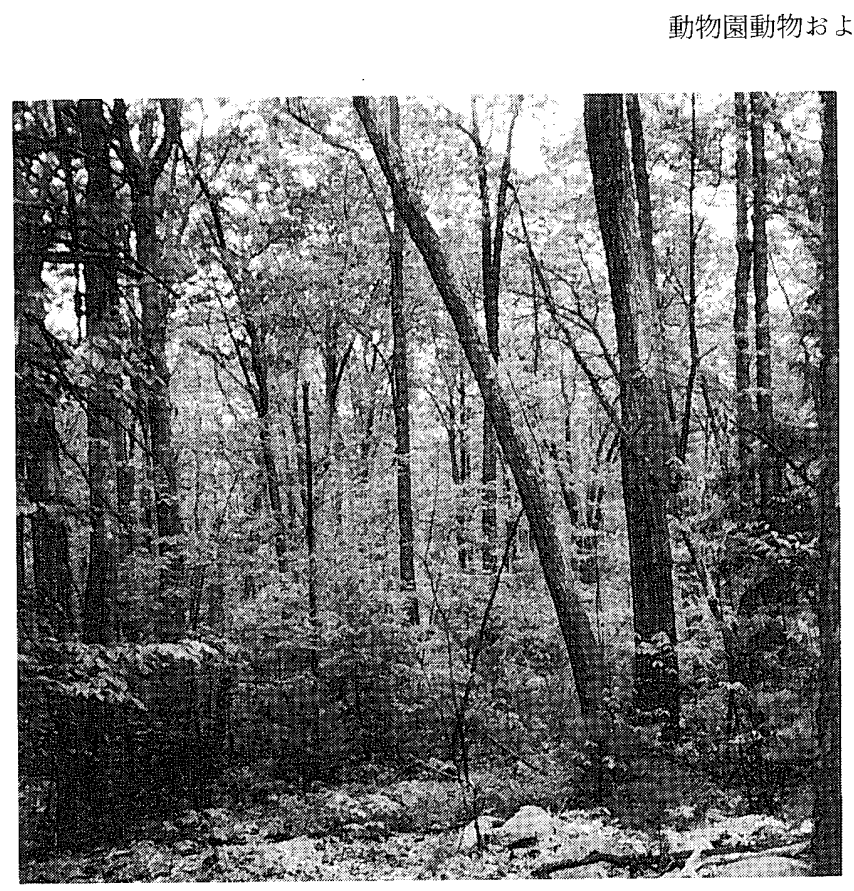

図 6 米国東部の森林

ライム病, 西ナイル熱, 狂犬病の流行地。

患者が近年増加傾向にある [24-26]。同症は早期㴟診断, 治 療を行えば問題ないが, 慢性化すると関節炎, 心㵴障害, 脳 神経炎が引き起こされ致命的となる [24-26]。ボレリアは マダニ類が媒介し, げっ歯類, シカ類などの野生動物も人 と共に感染環に入っており，森林の再生に伴いシカなどマ ダニの吸血源が増えたために，患者が増加傾向にあると考 えられている。寄生虫性疾患としては, 北海道を中心に多 包性エキノコックス(多包虫症)の人への感染が大きな問題 となる $[27]$ 。同寄生虫は，ネズミ類を中間宿主，キタキツ ネや犬を終宿主とし, 宿主の移動と共に感染地域が拡大し, 人へは污染された水, 野菜などを通じて感染する。一方, 本 州，四国，九州の河川では，ウエステルマン肺吸虫症の患 者の発生が依然として散発している $[28]$ 。中間宿主のモク ズガニを調理不十分なままで攝取，あるいは待機宿主であ るイノシシの生肉を食することで感染する。また, 最近, 移 入動物の一つであるアライグマに寄生するアライグマ回虫 の異宿主である人への迷入が問題視されている $[29]$ 。同寄 生虫は,人の脳など様々な組織で幼虫移行症による激甚な 障害を引き起こし，しばしば致死的となる。

サル類は進化の点からも人に近く様々な感染症を共有す るので, サルと人が接触する機会が多い動物園や医用実験 室で，それらの感染と防御が問題になる。まず，A 型肝炎
は飼育者からサル類に伝達され，逆に感染サルが人への感 染源となる $[30]$ 。単純へルペスウイルス (HSV-1 と HSV -2）は, 人から新世界ザルのマーモセットとタマリンに伝達 されると，極めて致死的であり，動物側が一方的に被害者 となる [31]。同様に人のギョウチュウEnterobius vermicularis は，チンパンジーに感染すると，移行症による激 甚な症状を示して整死する場合がある [32]。マカク属サル 類では，依然として Mycobacterium tuberculosis と Mycobacterium bovis による結核症が検疫上重要な感染症 でアアカゲザルが最も高い感受性を示すとされている [33,34]。また, Entamoeba histolyticaによるアメーバ赤痱 および Shigella 属細菌による細菌性赤痢は, 飼育者への感 染の点からも目が離せない。 B ウイルスに関しては, 血清 検查で陽性のマカク属サルがしばしば認められているが, 動物園での人の発症は欧米, 国内とも全くなく, 実験室で も発生頻度は極めて低いことから，実際の感染性について は多くの疑問を残している $[35]$ 。フィロクルスでは，ウ ガンダ産アフリカミドリザルを感染源とする人でのマール ブルグウイルス感染が致死的な出血熱として重要であるが [36]，ガボン北部森林で死亡していたチンパンジーから感 染したエボラ出血熱でも多くの死亡患者が認められた [37］。一方，米国とフィりピンにおけるカニクイザルの飼 育群に，エボラウイルス Reston 株による集団死亡がみら れたが，人ではエボラウイルス抗体陽性にもかかわらず発 症例は認められていない[38]。しかし，人への病原性につ いては不明な点が多いので注意を必要とする。レトロウイ ルスに関して，アフリカ産サルに由来するSIV には，人の HIV (特に HIV 2 型) に近縁のものがあり，人の HIV はサ ル由来であると推測されている。アフリカ産サルの SIV が アジア産マカク属のアカゲザルに伝播された場合, 人の HIV 患者に扔けるAIDS と酷似した病態が現れる [39]。 SIV を実験的に接種したアカゲザルの多くは 1 年以内に AIDS に陥り，人の AIDS 患者とほぼ同様な日和見感染症 が高率に認められる。最も頻繁に認められるのは， Pneumocystis carinii 肺炎, サイトメガロウイルス感染症, 非定型抗酸菌症，アデノウイルス感染症などである $[39,40]$ 。

\section{我が国で問題になる可能性のある野生動物感染症}

我が国で動物園動物および野生動物で問題となる可能性 
柳井德磨ら

表 1 我国で問題になる野生動物感染症

\begin{tabular}{|c|c|c|}
\hline 感染症 & 動物 & 文献 \\
\hline \multicolumn{3}{|l|}{ 1. 野外に棲息する鳥類, 哺乳類 } \\
\hline 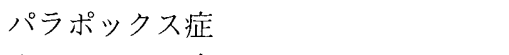 & ニホンカモシカ & 14 \\
\hline オーエスキー病 & 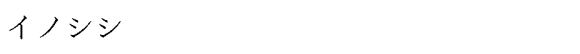 & \\
\hline ジステンパー感染症 & タヌキ，ハクビシン，アザラシ & 6,7 \\
\hline ライム病 & シカ類，ネズミ類(保菌動物として) & $24-26$ \\
\hline クロストリジウム症 & カラス & \\
\hline エキノコックス症 & キタキツネ，ネズミ類(感染源として) & 27 \\
\hline トリヒナ & クマ & \\
\hline 疥癬 & タヌキ & 5 \\
\hline アスペルギルス症 & 猛禽類, 鵜 & \\
\hline \multicolumn{3}{|c|}{ 2. エキゾチックペットおよび動物園動物における感染症 } \\
\hline 馬鼻肺炎 (EHV 1, EHV 4) & ウマ科動物 & \\
\hline 悪性カタール熱 & ウシ科, シカ科動物 & 12 \\
\hline B ウイルス & マカク属サル類(感染源) & 35 \\
\hline サーコウイルス感染症 (PBFD) & オウム類 & \\
\hline 結核症(人型，牛型結核菌) & サル類, 象, ウシ科動物, シ力科動物 & 33,34 \\
\hline 非定型的坑酸菌症(鳥型結核菌) & 鳥類，マカク属サル類 & 40 \\
\hline ヨーネ病 & ウシ科動物 & \\
\hline エルシニア症 & チンパンジー, リスザル & \\
\hline サルモネラ症 & カメ類, トカゲ類 & 21 \\
\hline クラミジア症(オウム病） & オウム類, シカ類 & 22 \\
\hline クリプトスポリジウム症 & トカゲ類, 蛇類 & \\
\hline トキソプラズマ症 & サル類, 鳥類，ハイラックス & 22 \\
\hline 真菌感染(アスペルギルス，カンジダ) & ペンギン類 & \\
\hline \multicolumn{3}{|l|}{ 3. 将来侵入する可能性のある海外感染病 } \\
\hline 西ナイル熱 & ほとんどの鳥類, 哺乳類, 爬虫類, 両生類 & $41-43$ \\
\hline ニパウイルス & フルーツ蝙蝠(感染源) & 23 \\
\hline エボラ出血熱レストン株 & カニクイザル & 38 \\
\hline 口蹄疫 & 偶蹄類 & \\
\hline ペスト & げっ继類(感染源) & 22 \\
\hline BSE & 野生猫科動物，ウシ科動物 & 2 \\
\hline 狂犬病 & 蝙蝠類, サル類, 小型食肉哺乳類 & 45 \\
\hline
\end{tabular}

の高い新興および再興感染症について表 1 に示した。中で も近い将来, 海外から侵入し野生動物の生息環境および社 会に大きな影響を与える西ナイルウイルスと狂犬病につい て，以下に述べる。

\section{西ナイルウイルスについて}

現在, 米国では西ナイルウイルス (WNV) (図 7)が，ハワ イやアラスカを除くほとんどの州，さらにカナダに拡がっ ている[41]。我が国に WNV が侵入する可能性はあるのだ ろうか？との疑問には, 可能性ありと返答せざるを得ない。 WNVが米国へ侵入したと疑われている経路は，我が国に おいても大いに該当する。すなわち，海外で感染した人が
国内に入国して発症する可能性，旅行者が感染した動物を 持ち込む可能性(密輸もあり), 台風で感染した鳥が遠隔地 から運ばれる可能性，さらにアルカイダのようなテロリス 卜が持ち込む可能性がある。いずれの場合も，可能性は高 く, 特に国内に多数輸入されるエキゾチックペットは, WNV の reservoir となりうるし，一旦侵入すれば，日本産 イエカも直ちにWNV の媒介者となる可能性が高い。 米国における西ナイルウイルスの急激な流行は, 多くの 絶滅危惧種への影響が心配されている。1998 年ニューヨー クで初発時に多数のカラスの憼死が確認され, それらの病 理検査では脳炎と心筋炎が認められ，WNV が分離された 


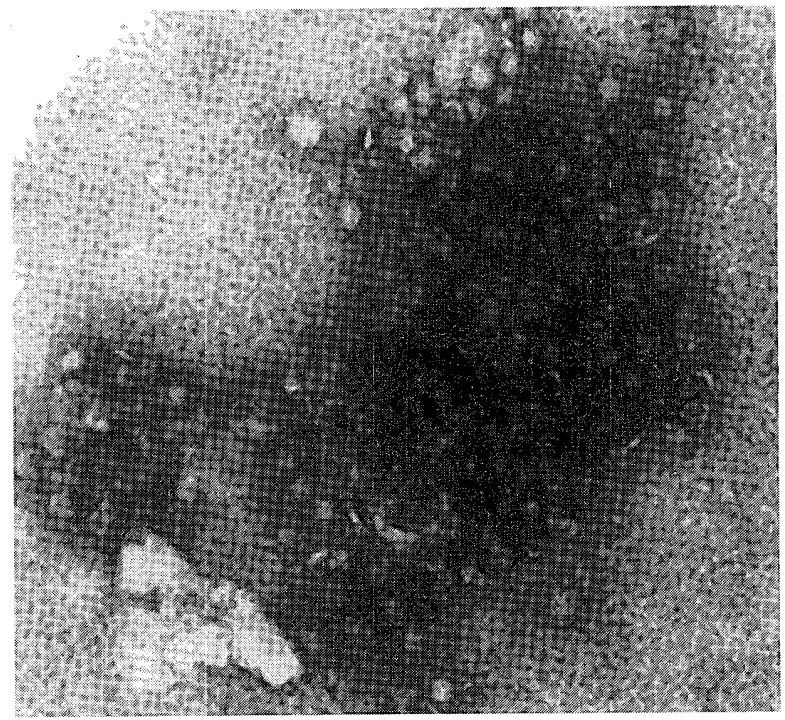

図 7 西ナイルウイルスの電顕像

(Courtesy of Dr. Joshua Dein, USGS)

$[42,43]$ oWNV は，個体数の少ないハゲワシ類や絶滅危惧 種である Mississippi Sandhill Craneなどで感染が確認 されている。WNVのこれほど急速な感染の拡大は予想で きなかったので,ワクチンを含めた, 絶滅危惧種への WNV 対策もほとんど有効なものはない。今回の WNV 流行から 免れたとしても，猛禽類にとって餌となる小鳥の個体数が 激減した場合，必然的に大きな影響を受けると推測される。 今回の北米におけるWNV の流行が, 各種の野生動物に与 える影響については，慎重に評価する必要がある [43]。

$\mathrm{WNV}$ の伝播には，蚊が大きな役割を担っている。北米 の何処にでもいるイエカ属が WNV を媒介し，蚊がいない 所では，ダ二などの吸血節足動物が媒介する。多くの場合， 鳥類と蚊が WNV を相互に保持し増殖して遠隔地に運ん でいる。実験的に，WNV を接種した鴨では，100日に亘り WNVの持続感染が確認された。地域によっては, 蛙と蚊 のサイクルも成立していると推測される。人の WNV 患者 から健康な人に，接触しただけでは感染しないが，鳥では WNV 感染個体と健康個体を同居させると, 健康な鳥も感 染する。

死亡した野鳥を採取してWNV の感染状況を検査する ことが，このウイルスの感染の拡大状況を知る正確な方法 である。例えば, カラス類は移動しても，その範囲は200マ イル以下なので，その地方での鳥類の WNV 感染の状態を よく反映すると考えられる。1999 年から米国では

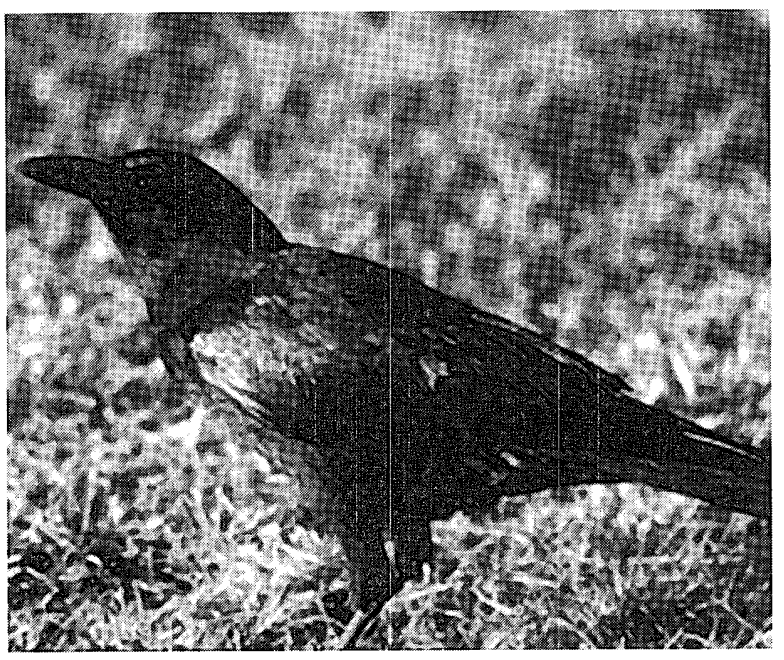

図 8 アメリカガラス

(Courtesy of Dr. Joshua Dein, USGS)

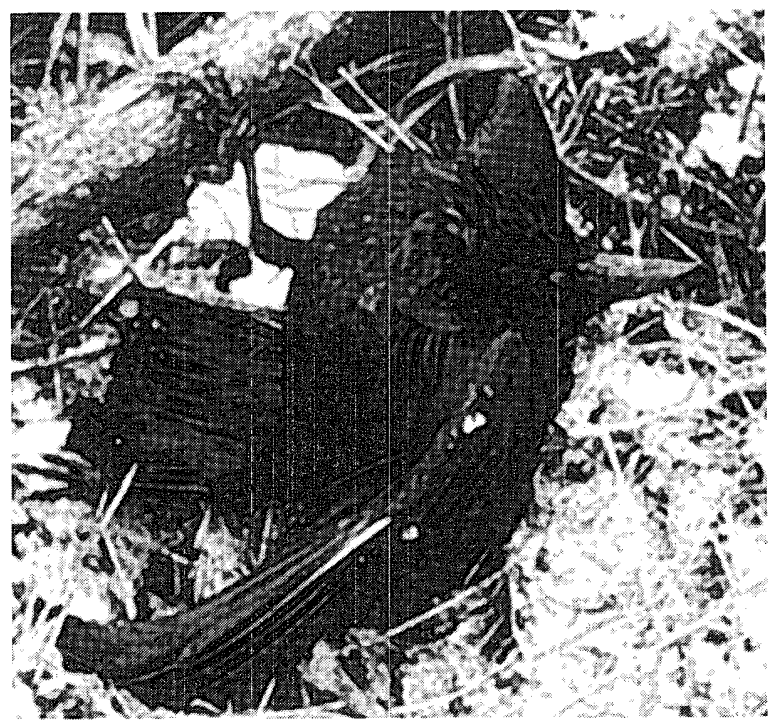

図 9 西ナイルウイルスに感染して憼死したカラス (Courtesy of Dr. Joshua Dein, USGS)

National Wildlife Health Center など幾つかの野生動物 疾病研究所が中心になり, 擎死した野鳥を検査してWNV 感染状況を把握し，インターネットで公開するプロジェク トが活動している。その結果, 2002 年 12 月の時点で, 北米 の鳥類固有種のうち 136 種，スズメなど移入種の 9 種で WNV が見つかっている [42]。また，アメリカガラス(図 8)，ウオクイカラス，アオカケスが特にWNVに対して高 い感受性を示すことが明らかになった。1998 年の発生当初 
はカラスがWNVに感染し死亡率も高いことから要注意 とされたが(図 9), WNVがメキシコ湾岸や中西部に拡が るにつれて，アオカケスでの WNV 保有率が高くなってい る。この他, ペットとして飼育されているオウム類, 動物 園で飼育されている猛禽類, ツル類,ペンギン類にもWNV が検出されている。

野外に生息する小型哺乳類では,オオクビワコウモリ，ト ビイロホオヒゲコオモリ，その他スカンク，リスなどにも WNV の保有がみられる。また, 養殖ワニにもWNVによ る多数の死亡例が認められている。動物園のアシ力類など 多種類の哺乳動物からもWNVが見つかっていることか ら,これらの動物の移動についても，WNVに対する適正 な検疫体制が必要である。

\section{狂犬病侵入と野生動物}

米国では, 種々の野生動物が狂犬病ウイルスに感染し, 犬 および猫に替わって流行の担い手となっている[44]。すな わち, 中西部ではスカンク, キツネ, 南部ではアライグマ, 全米でコウモリが感染動物となっている。最近, 韓国では, 一旦消滅した狂犬病が, 38 度線非武装地帯からの感染野生 動物の侵入により復活し, 再び定着して, 野生動物を介し て増加傾向に転じている。我が国は, タヌキ, キツネ,ア ライグマなど幾種類かの感受性野生動物を有しており，一 旦，狂犬病の侵入を許せば，野生動物を介して定着する可 能性がある $[45]$ 。そのため, 狂犬病の危機管理として野生 動物での伝播への対策を立案する必要がある。極東では政 治情勢の流動化に伴い, 感染動物が存在する可能性が高い 北朝鮮から人や動物が日本海沿岸に漂着し, 韓国と同様, 日 本でも野生動物を中心に狂犬病が定着する可能性が皆無と はいえない。

\section{野外で死んだ鳥や野生動物を多数見つけた場合は？}

決して素手で取り扱わないで，ゴム製の手袋を装着して 扱う必要がある。解剖は, できるだけ野生動物の病理の専 門家に依頼した方が良い。野生動物の多数の死亡を確認さ れた方，あるいは野生動物の感染症に関する疑問をおもち の方は, 肢阜大学農学部獣医病理学教室・柳井徳磨までご 連絡下さい(E-mail yanai@cc.gifu-u.ac.jp, Tel $058-293-2944)$ 。

\section{終わりに}

今後とも, 野生動物医学において感染症の比重は益々増
加すると考えられる。そのため, 早急に, 野生動物医学会, 国立感染症研究所, 独立法人動物衛生研究所などの関連部 署との連携による, 感染症情報の管理と普及を目的とした 感染症ネットワークの構築が必要である。今回, 紹介した 米国における西ナイル熱のように, 野生動物が病原体の伝 播において重要な役割を担う感染症の解明と防疫には, 野 生動物医学からのアプローチが不可欠である。そのため, 野 生動物医学における感染症研究の拠点となる, 国立あるい は大学付属のセンターの設立が望まれる。

ところで, 最近, 動物園や水属館では, 財政状態の大幅 な悪化に伴い, 獣医師を外部委託に頼る傾向がある。今回 のワークショップで紹介したクラミジア症の発生で明らか になったように, 日常的に疾病管理に努める常勤獣医師を 欠く動物園では, 感染症に対する危機管理能力が極端に低 下することが，大きな教訓として示された。感染症の防止 には，ある程度のコスト負担が必要であることを経営側も 理解する必要がある。

\section{要 約}

動物園動物および野生動物の感染症をモニターすること は，動物の損失を食止めるために極めて重要であり，野生 動物の保護管理, 家畜衛生, 人獣共通感染症の防止に大き く寄与する。そのため, 我々は野生動物の疾病コントロー ルに有用な最新の情報を共有する目的で, ワークショップ

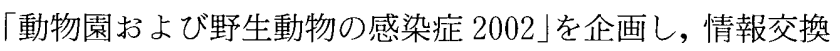
を試みた。今回, 現在, 最も緊急性の高い感染症, あるい は注意を喚起したい感染症として，動物園動物におけるク ラミジア症(鳥類, ヘラジカ), サル類におけるエルシニア 症，爬虫類におけるクリプトスポリジウム症および動物園 および野生動物における海綿状脳症について取り上げた。 その他, 今後, 我が国で問題になりうる幾つかの感染症に ついても概説した。動物園動物および野生動物の感染症コ ントロールを目的とした野生動物医学会内でのネットワー ク形成, さらに公的な野生動物感染症研究センターの設立 が望まれる。

キーワード：感染症, 動物園動物, 野生動物

\section{謝辞}

本研究の一部は文部科学省 21 世紀 COE プログラムお よび厚生労働省厚生科学研究費の補助により実施した。 
ワークショップ「速報, 動物園および野生動物感染症 2002」 の開催に便宜を頂いた第 8 回野生動物医学会大会長溝口俊 夫氏に深謝する。また，西ナイルウイルスおよびカラスの 写真を快く提供して下さったUSGS National Wildlife Health Center の Joshua Dein 博士に心より感謝する。

\section{引用文献}

1. 中村靖彦.2001. 狂牛病, 岩波新書, 岩波書店, 東京

2. 杉山 誠. 2003. シカ類のプリオン病一慢性消耗性疾患 (CWD). 畜産 の研究 (印刷中)

3. 近辻宏帰. 2002 . 卜キ保護センターの 16 年の記録. トキ永遠なる飛翔 (近辻宏㷌編), pp.110-121. Newton Press, 東京

4. 村田浩一, 浜 夏樹, 安田伸二.1996. 飼育下タンチョウの幼鳥に認め られた原虫感染症, 日本野生動物医学会誌 1: 33-37.

5. 遠藤浩範. 1996. タヌキ. 野生動物救護ハンドブック(野生動物救護ハ ンドブック編集委員会編），文永堂出版，東京：179-187.

6. Machida N, Izumizawa N, Nakamura T, Kiryu K. 1992. Canine Distemper Virus Infection in a Masked Palm Civet (Paguma larvata). J Comp Pathol 107: 439-443

7. Machida N, Kiryu K, Oh-ishi K, Kanda E, Izumisawa N, nakamura T. 1993. Pathology and epidermiology of canine distemper in raccoon dogs (Nyctereutes procyonoides). J Comp Pathol 108: $383-392$.

8. Morell V. 1994. Canine distemper virus. Serengeti's big cats going to the dogs. Science 264: 1669

9. 甲斐知恵子. 1994。野生動物のジステンパーウイルス感染症, 獣医畜 産新報 47: 25-28.

10. Hama N, Murata K, Noda A, Kawaguchi M, Sakai H, Masegi T, Sasseville V, Yanai T. 1998. Feline infectious peritonitis in a manul. Jpn J Zoo Wild Med 3: 53-58.

11. 千葉熖孝. 1993. 動物園動物の病理学, 近代文藝社, 東京

12. Plowright W.1981. Herpesviruses of wild ungulates, including malignant catarrhal fever virus. In Infectious Diseases of Wild Mammals (Davis JW, Karstad LH, Trainer DO eds), pp.126-153. The Iowa State University Press, Ames.

13. Plowright W.1981. African swine fever. In Infectious Diseases of Wild Mammals (Davis JW, Karstad LH, Trainer DO eds), pp.178-190. The Iowa State University Press, Ames.

14. 相木利昭, 堀 充陽, 酒井洋樹, 猪島康男, 柳井徳磨. 2002. 野生二木 ンカモシカに颃けるパラポックスウイルス感染症：ヒツジへの伝播の可 能性. Jph J Zoo Wild Med 7: 39-43.

15. Yanai T, Sakai T, Fukushi H, Hirai K, Narita M, Sakai H, Toshiaki M. 1998. Neuropathological study of gazelle herpesvirus 1 (equine herpesvirus 9) infection in Thomson's gazelle (gazella thomsonii). J Comp Pathol 119: 159-168.

16. Taniguchi A, Fukushi H, Yanai T, Masegi T, Yamaguchi $\mathrm{T}$, Hirai K. 2000. Equine herpesvirus 9 induced lethal encephalomyelitis in experimentally infected goats. Arch Virol 145: 2619-2627.
17. Fukushi H, Taniguchi A, Yasuda K, Yanai T, Masegi T, Yamaguchi T, Hirai K. 2000. A hamster model of equine herpes 9 induced encephalitis. J Neurovirol 6: 314-319.

18. Yanai T, Tsujioka S, Sakai H, Fukushi H, Hirai K, Masegi T. Experimental infection with equine herpesvirus $9(\mathrm{EHV}-9)$ in cats. J Comp Pathol (in press)

19. Yanai T, Fujishima N, Fukushi H, Hirata A, Sakai H, Masegi T. Experimental infection of equine herpesvirus 9 (EHV -9) in dogs. Vet Pathol (in press)

20. Taniguchi A, Fukushi H, Matsumura T, Yanai T, Masegi T, Hirai K. 2000. Pathogenicity of a neurotropic equine herpesvirus 9 (Gazelle herpesvirus 1) in horses. J Vet Med Sci 62: 215-218.

21. 吉川泰弘. 2000. 動物由来感染症と検疫. 感染症 30: 169-180.

22. 吉川泰弘. 2000。輸入動物によるエマージングウイルスへの対策. Sut Bulleten 2: 7-15.

23. 小沢義博. 2000. 二パ(Nipah)ウイルス感染症について(第1 報). $J$ Vet Med Sci 62: J 21-29.

24. 宮本健司, 中尾 稔, 橋本喜夫. 1994. 北海道见おけるライム病発生の 要因と現状.ダニと疾患のインターフェイス(SADI 組織委員会編), pp.123-128. YUKI 書房, 東京

25. Burgdorfer W, Barbour A, Hayes SF, Benach JL, Grunwaldt E, Davis JP. 1982. Lyme disease-A tick-borne spirochetosis? Science 216: 1317-1319.

26. CDC. 1991-1992. Lyme disease in the United States. MMWR 42: $345-348$

27. 佐藤直樹，宇根良衛，内野純一１997.エキノコックス症．新興再興感 染症 (山口恵三編) pp.96-101. 日本医事新報社, 東京.

28. 嶋田雅眰. 1997.グルメと寄生虫疾患。新興再興感染症 (山口恵三編) pp. 102-109.日本医事新報社, 東京.

29. 宮下 実. 2000. 日本の移入動物，アライグマの現状とその危険性. 第 6 回日本野生動物医学会大会講演要旨集(鳥取)，pp. 82 .

30. Ramsey E, Montali RJ. 1993. Viral hepatitis in new world primates. In Zoo and Wild Animal Mediciene: current Therapy 3 (Fowler M, Miller RE eds.), pp. 355-358. W.B. Saunders, Philadelphia

31. Juan-Salles C, Ramos-Vara JA, Prats N. 1997. Spontaneous herpes simplex virus infection in common marmosets, Callithrix jacchus. J Vet Diagn Invest 9: 341-345.

32. Murata K, Hasegawa H, Nakano T, Noda A, Yanai T. 2002. Fatal infection with human pinworm, Enterobius vermicularis, in a captive chimpanzee. J Med Primatol 31: 104-108.

33. King NW. 1993. Tuberculosis. In Monographs on Pathology of Laboratory Animals: Nonhuman Primates I (Jones TC, Mohr U, Hunt RD eds.), pp.141-148. Springer-Verlag, Berlin.

34. Lapin BA, Yakovleva LA. 1960. Tuberculosis. In Comparative Pathology in Monkeys, pp.65-105, Charles C Thomas Publisher, Springfield, Il.

35. Montali RJ. 1995. B virus in zoo macaques: Current issues. Proc. Joint Conference AAZV/WDA/AAWV, 235-267.

36. Martini GA. 1969. Marburg agent disease in man. Trans $R$ Soc Trop Med Hyg 63: 295-302. 


\section{柳井徳磨ら}

37. WHO. 1996. Outbreak of Ebola haemorrhagic fever in Gabon officially declared over. Wkl Epidemiol Rec 71:125-126.

38. WHO. 1992. Viral hemorrhagic fever in imported monkeys. Wkl Epidemiol Rec 67:142.

39. Simon MA, Chalifoux LV, Ringler DJ. 1992. Pathologic features of SIV-induced disease and the association of macrophage infection with disease evolusion. AIDS Res Human Retrovirus 8: 327-337.

40. Mansfield KG, Pauley D, Young HL, Lackner AA. 1995. Mycobacterium avium complex in macaques with AIDS is associated with a specific simian immunodeficiency virus and prolonged survival after primal infection. J Infect Dis 172: 1149-1152.

41. CDC. 2002. Provisional surveillance summary of the West Nile virus epidemic-United States, January-November 2002. MMWR 51: $1129-1133$.
42. Anderson JF, Andreadis TG, Vossbrinck CR, Tirrell S, Wakem EM, French RA, Van Kruining HJ. 1999. Isolation of West Nile virus from mosquitoes, crows, and a cooper's hawk in Connecticut. Science 286: 2331-2333.

43. Steele KE, Linn MJ, Schoepp RJ, Komar N, Geisbert TW, Manduca RM, Calle PP, Raphael BL, Clippinger TL, Larsen T, Smith J, Lanciotti RS, Panella NA, McNamara TS. 2000. Pathology of fatal West Nile Virus infections in native and exotic birds during the 1999 outbreak in New York city, New York. Vet Pathol 37: 208-224.

44. Sikes RK. 1981. Rabies. In Infectious Diseases of Wild Mammals (Davis JW, Karstad LH, Trainer DO eds), pp.3-17. The Iowa State University Press, Ames

45. 源宣之. 2001. 日本は現状の防疫対策で狂犬病の再発を防げるか． 移入・外来・侵入種一生物多栏性を脅かすもの(川道美恵子，岩梘邦男，堂 本暁子編)，pp.252-263．築地書館, 東京 